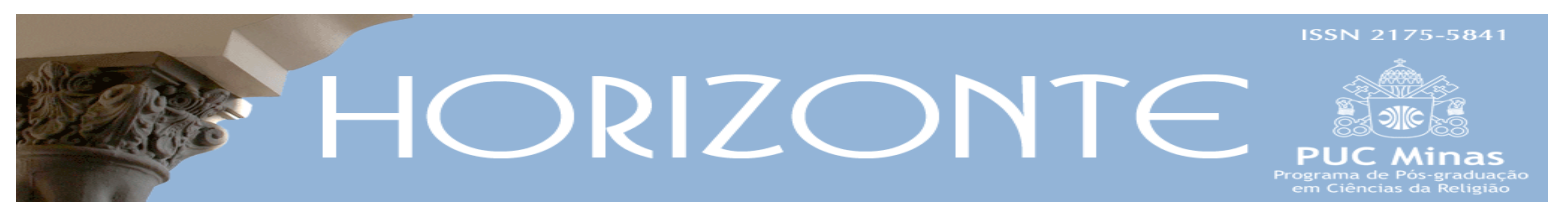

Temática Livre - Artigo Original

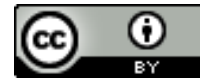

DOI - 10.5752/P.2175-5841.2018v16n51p1218

\title{
Passos levinasianos rumo à evasão da teologia ocidental
}

\author{
Levinasian steps toward the evasion of western theology
}

\author{
Luis Carlos Dalla Rosa*
}

\begin{abstract}
Resumo
Este artigo abre espaço para discutir a relação entre teologia e ontologia, a partir da ética da alteridade de Emmanuel Lévinas. Trata-se de analisar e compreender o movimento de êxodo ou de evasão ética em relação à força ontológica, ao peso do ser, que impacta também à teologia. O sujeito, exposto à aventura do ser, é alguém cativo de si mesmo. Por outro lado, cabe refletir sobre algumas possíveis repercussões teológicas que emergem da epifania do rosto do/a Outro/a. Pois, embora Lévinas trilhe mais pelo caminho da filosofia, sua obra se deixa conduzir pela sabedoria bíblico-talmúdica. De modo que há, na ética levinasiana, um ressoar do teológico, uma espécie de ferida que lateja e testemunha um vestígio, um eco do Infinito no rosto da viúva, do órfão e do estrangeiro. A entrada de um/a Outro/a anuncia o tempo da esperança quando aparentemente já não há mais esperança. Então, o milagre que salva o mundo, anúncio de uma boa-nova que comunica o Verbo que se fez carne. Essa é também possibilidade do bem, da exposição - hospitalidade - do eis-me aqui e, então, envia-me.
\end{abstract}

Palavras-chaves: ética da alteridade; ontologia; rosto; êxodo.

\begin{abstract}
This article opens space to discuss the relationship between theology and ontology, based on the otherness ethics of Emmanuel Lévinas. It is about analyzing and understanding the movement of exodus or ethical evasion in relation to the ontological force, to the weight of being, which also impacts theology. The subject, who is exposed to the adventure of being, is a captive of himself. On the other hand, it is necessary to reflect on some possible theological repercussions that emerge from the epiphany of the face of the Other. For though Lévinas treads more on the path of philosophy, his work is guided by Biblical-Talmudic wisdom. So there is in the Levinasian ethics a resounding theological, a kind of wound that beats and bears a vestige, an echo of the Infinite in the face of the widow, the orphan, and the stranger. The entrance of one Another announces the time of hope when there is apparently no longer any hope. Then the miracle that saves the world, the announcement of a good news that communicates the Word that became Flesh. This is also the possibility of the good, the exhibition - hospitality -, of the here I am, and then send me.
\end{abstract}

Keywords: ethics of alterity; ontology; face; exodus.

Artigo submetido em 10 de julho de 2017 e aprovado em 20 de dezembro de 2018.

* Doutor em Teologia pelas Faculdades EST, São Leopoldo. Professor na Faculdade Dom Bosco, Porto Alegre - RS. País de origem: Brasil. E-mail: Icdr75@hotmail.com

Horizonte, Belo Horizonte, v. 16, n. 51, p. 1218-1239, set./dez. 2018 - ISSN 2175-5841 


\section{Introdução}

Lê-se no Salmo 119: "Eu sou estrangeiro sobre a terra, não me ocultes teus mandamentos". [...] Eco do dizer permanente da Bíblia: a condição - ou incondição - de estrangeiros e de escravos no país do Egito reaproxima o [humano] do próximo. [...] A diferença que se abre em mim e si (moi et soi), a não coincidência do idêntico, é uma radical não indiferença em relação aos homens. (LÉVINAS, 1993b, p. 104).

Este artigo discute a relação entre teologia e ontologia, tendo, como critério de análise hermenêutica a ética de Emannuel Lévinas (1906-1995), filósofo de origem judaica nascido na Lituânia e radicado na França. De forma específica, problematiza-se a saída do ser, enquanto um movimento de êxodo que fissura a totalidade ontológica, a supremacia de um ser ensimesmado, e abre a relação ao/à Outro/a, em sua alteridade. Instigado pela opressão da viúva, do órfão e do estrangeiro (Jr 7.6), Lévinas provoca um pensar ético sobre a aproximação do/a Outro/a, a partir da filosofia, mas que implica também a teologia. O esforço aqui consiste, a partir da filosofia levinasiana, refletir a interface teológica, "uma ética teológica sem ontologia”, como propõe Ribeiro Júnior (2008, p. 445). "De Deus que vem a ideia em mim”, diz Lévinas. Isto é, revelação que se dá na relação com o próximo. De modo que "pensamos que a ideia-do-Infinito-em-mim - ou na minha relação a Deus - vem a mim na concretude de minha relação ao outro homem, na sociabilidade que é minha responsabilidade para com o próximo" (LÉVINAS, 2002, p. 15).

No dizer de Bucks (1997, p. 33), "uma vez que a tradição cristã está enraizada no judaísmo”, e Lévinas pensa também a partir da sabedoria judaica, “a investigação possui relevância também para a teologia cristã”. Não obstante, entende-se que "a filosofia e a teologia ocidentais são sempre teosofia, teodiceia, teologia dialética, teologia racional etc., e, como tais, são incapazes de Deus. A lógica de Deus - teo-lógica - é ilógica se pensada em função da onto-teologia” (RIBEIRO JÚNIOR, 2008, p. 446). Ora, Lévinas ousa questionar essa forma de pensar o logos que ocupa também a teologia, um discurso que se torna, muitas vezes, vazio da revelação de Deus que toca minha sensibilidade na relação com 
outrem. De modo que colocar em suspeição a ontologia teológica, na expectativa deste artigo, abre-se a possibilidade de uma ética teológica, uma teologia orientada para a vida, porque Deus é o Deus da vida. "Deus-vindo-à-ideia, como vida de Deus” (LÉVINAS, 2002, p. 16), que se coloca como sabedoria do amor, amor a serviço do próximo.

O texto se desenvolve a partir de três pontos básicos. Com efeito, a primeira parte trata da fadiga do ser que, no momento mais dramático, expressa o entusiasmo da filosofia do hitlerismo e tudo mais o que isso implica. Daí o sentido da evasão levinasiana que busca romper com o primado do ontonlógico. O segundo ponto centra esforço no singular conceito levinasiano do há (il y a), em que a promessa ontológica é posta em questão, justamente a partir da entrada do/a Outro/a. Palavra que desassossega e cria sentido no ser para o/a Outro/a. Por fim, na terceira secção, trata-se de explicitar o sentido da Palavra que ressoa no clamor que vem da outra margem, testemunho de uma possível teologia sem ontologia ou de uma ética teológica como vestígio de Deus no rosto do próximo. "Não tenho receio da palavra Deus, que aparece muitas vezes nos meus ensaios. O Infinito vem-me à ideia na significância do rosto. O rosto significa o Infinito" (LÉVINAS, 2000, p. 97).

\section{Tempo de evasão: ama teu próximo}

As obras maduras de Lévinas, a saber, Totalidade e infinito (Totalité et infini - 1961) e De outro modo que ser ou mais além da essência (Autrement qu'être ou Au-delà de l'essence - 1974), expressam de forma contundente o projeto filosófico do autor, em que o rosto do/a Outro/a se torna sentido de ser-no-mundo (proximidade) e transcendência (abertura, Infinito). Essa é a perspectiva que marca a compreensão levinasiana da subjetividade implicada pela responsabilidade ética ou do responder pelo/a Outro/a. Não obstante à centralidade das obras supracitadas, o esforço aqui é problematizar o sentido da subjetividade ou do sentido do humano que Lévinas implica já nos primeiros passos de seu itinerário, 
na relação entre a filosofia e a sabedoria bíblica, e que coloca em questão um dos momentos mais dramáticos do século $\mathrm{XX}$, o nazi-fascismo e, com ele, todo o contexto da Segunda Guerra, Auschwitz, Hiroshima e Nagazaki.

Em Lévinas, há um pensador que sofre, na própria carne, o terror da Segunda Guerra Mundial, com todo o peso do que significa o antissemitismo, a detenção sua no cativeiro, o assassinato de seus pais, irmão e sogros no campo de concentração nazista. Do mesmo modo, trata-se de um pensador que remete ao rosto do/a Outro/a que é vítima de toda sorte de ódio, fanatismo, injustiça e ganância que prossegue no tempo atual. Com efeito, Lévinas estende sua experiência e pensamento “à memória dos seres mais próximos entre os milhões de assassinados pelo nazismo, ao lado de milhões e milhões de humanos de todas confissões e nações, vítimas do mesmo ódio ao outro humano, do mesmo antissemitismo" (LÉVINAS, 2003a, p. 07).

Ora, o que está em pauta não são apenas os acontecimentos históricos em si, mas o idealismo transcendental, presente também na teologia cristã, da civilização que ajudou a produzir Auschwitz. Um mesmo idealismo que, quiçá, não obstante aos amplos esforços para evitar que Auschwitz se repita, tem pautado novos e aterradores totalitarismos, hoje. Isso não tanto em nome de um Estado, mas de ideologias, inclusive religiosas, e sistemas econômicos que avassalam a dignidade humana, destroem o meio ambiente. Enfim, o avanço atual do extremismo religioso, econômico e político sinaliza de que se está diante de uma nova derrocada humana. Daí também a importância de se ouvir, mais uma vez, os alertadores de fogo, um alerta que permanece presente, em nosso contexto, pelo testemunho da própria obra, como é o caso da ética da alteridade levinasiana.

Em Algumas reflexões sobre a filosofia do hitlerismo, artigo publicado em 1934, Lévinas expressa considerações sobre a filosofia nazista, além de alertar do fogo, isto é, do perigo que se aproximava com o regime de Hitler. Para ele, "mais do que um contágio ou uma loucura, trata-se o hitlerismo de um despertar de 
sentimentos rudimentares", pois, além de "entranhar um imenso perigo", tal filosofia "desborda a filosofia dos hitlerianos, colocando em causa os próprios princípios de uma civilização”. Nesse contexto, continua Lévinas (2006. p. 25), “o próprio cristianismo se encontra ameaçado apesar das concessões ou concordatas que beneficiaram as igrejas cristãs à chegada do regime”. Sobre os resultados e consequências da ideologia nazista, da guerra e tudo mais o que isso significa em termos do inumano, inimaginável, de crime e indiferença, a história percorre como testemunha dos horrores que teimam em se repetir, não obstante aos esforços para que isso não volte a acontecer.

Já numa leitura retrospectiva, sobre esse mesmo contexto, em uma de suas últimas entrevistas, Lévinas (2007, p. 73) aponta para "essa espécie de desespero ininterrupto que foi o período hitleriano da Europa, erguendo-se do fundo dessa Alemanha tão fundamental, dessa Alemanha de Leibniz e de Kant, de Goethe e de Hegel”. E, vale acrescentar que, nesse fundo tão fundamental para a razão europeia, há a presença de Heidegger, cujo pensamento impacta também a obra de Lévinas, sobretudo ao que tange à análise ontológica. De fato, trata-se primeiramente de um diálogo receptivo em relação à fenomenologia existencial, presente, sobretudo, em Ser e tempo. Não é apenas uma admiração por essa obra que marca tal impacto, mas a percepção de que "as noções heideggerianas da finitude, do estar-aí, do ser-para-a-morte, etc., permanecem fundamentais" (LÉVINAS, 200o, p. 33).

Não obstante à proximidade, de Ser e tempo, na medida em que Lévinas assume a ética enquanto filosofia primeira, processo esse que ocorre como em um movimento de espiral, torna-se claro sua divergência relação ao solipsismo monádico. A ética levinasiana se contrapõe à ontologia heideggeriana quando esta implica a pretensão imperativa (conatus essendi), sob a qual, secundariza-se o sentido do humano, isto é, o rosto do/a Outro/a em sua alteridade. Mais do que uma crítica, o itinerário levinasiano enseja uma evasão, um movimento de êxodo, em relação ao peso do que significa o ser, na cultura ocidental, e que possibilita 
uma relação de proximidade. "Que pode significar o pôr-se em movimento para se colocar no lugar do outro senão a aproximação do próximo?” (LÉVINAS, 2002, p. 30).

Referindo-se à Da evasão, obra de 1935, Lévinas (2007, p. 72) diz que, nela, “é possível distinguir as angústias da guerra que se aproximava e toda a 'fadiga de ser' [...]. Desconfiança em relação ao ser [...], em uma época em que havia, por completo, o pressentimento do hitlerismo iminente por todos os lados”. Segundo análise de Fabri (1996, p. 26), “o clima presente em De L'évasion é de uma perda intelectual de sentido, pois, no caso de Lévinas, a existência ligada ao ser encontrava-se às vésperas dos grandes massacres que marcaram a história da Europa”. De certa forma, a desconfiança levinasiana em relação ao ser pode ser identificada como um prelúdio do êxodo inerente à ética da alteridade. O sujeito exposto à aventura do ser é alguém cativo de si mesmo. "O ser requer o homem como uma pátria ou um solo requer seus autóctones" (LÉVINAS, 2006, p. 96). De modo similar à figura mitológica de Narciso, apaixonado pela sua própria imagem, a pessoa permanece absorta em seu próprio ser e, desse modo, ensimesmada, está convencida de que está em paz e de consciência tranquila. Entende-se, aqui, uma denúncia ao processo de aburguesamento do Mesmo, isto é, “alienação, 'engordamento' que renega a alteridade opondo-se, na sua integridade, contra aquilo que a transcende e ainda a concerne” (LÉVINAS, 2002, p. 53).

Em outro passo, como saída do estado ontológico, Lévinas (1998a, p. 67) anuncia que, não obstante à pura experiência do há (do francês il y a), "essa 'consumição' impessoal, anônima, mas inextinguível do ser, aquela que murmura no fundo do próprio nada”, o evento da alteridade não apenas se contrapõe a todo niilismo, da morte de Deus ou da morte do humano, mas comunica um sentido de ser que se desborda a partir da própria manifestação ou presença do/a Outro/a. "Estamos rodeados de seres e coisas com as quais mantemos relações. Pela vista, pelo tato, pela simpatia, pelo trabalho em comum, estamos com os outros. Todas essas relações são transitivas. Toco um objeto, vejo o Outro; mas não sou o Outro" (LÉVINAS, 1993a, p. 80).

Horizonte, Belo Horizonte, v. 16, n. 51, p. 1218-1239, set./dez. 2018 - ISSN 2175-5841 
De modo que a manifestação do/a Outro/a anuncia a possibilidade de sair não apenas da solidão, mas do ser. Pois, sair de si mesmo, é encontrar uma alteridade, um/a Outro/a que não sou eu, nem mesmo uma projeção minha. Encontrar o/a Outro/a, na relação face a face, é o sentido que abre a hospitalidade do eis-me aqui - sabedoria do bem a serviço do amor. Nessa perspectiva, fora da ordem do ser, do discurso ontológico, "a ideia de Deus é Deus em mim, mas Deus já rompendo a consciência que visa a ideias, diferente de todo conteúdo" (LÉVINAS, 2002, p. 95). O Infinito em mim é também a ideia do bem em mim. Ora, no dizer de Costa (2000, p. 76), "o bem é sair de si-mesmo para o Outro-diferente-de-simesmo, para o diferente de si-mesmo".

Extrapolando ao contexto do judaico, na relação com o próximo, revela-se a Palavra (Verbo) que se torna carne na Sabedoria (Mandamento) do Amor, mas que o horror do ser, como em Auschwitz, teima, inclusive, reduzir a vítima à cinza, para não deixar rastro ou memória. "Auschwitz não foi apenas uma gigantesca fábrica de morte, mas um projeto de esquecimento. Tudo já estava pensado para que não ficasse nenhuma pista, por isso todos tinham que morrer e os cadáveres deveriam ser queimados, os ossos moídos e logo aventados" (MATE, 2005, p. 07). Humilhação até o esquecimento, apagamento da memória não apenas do rosto assassinado em Auschwitz, mas também do índio, do negro, da mulher, da transexual... enfim, vítimas da mesma lógica que, em nome da glória do ser, evoca a paz da guerra, isto é, a paz dos cemitérios.

Para entender o pensamento levinasiano, cabe aqui retomar o conceito de ontologia. Com efeito, desde Parmênides, século V a.c., de acordo com Legrand (1997, p. 86), a ideia básica de ontologia reside nas proposições de que "o ser é. Esse 'ser' é 'idêntico' ao pensamento conceitual. [...] O Mesmo, o Idêntico [...] é o que é simultaneamente 'ser' e 'pensamento'. [...] O Ser é, o Nada não é [...]”. Ou seja, em ser e pensamento, há uma mesma identidade. De modo que a ontologia é concebida como logos ou discurso que comunica o sentido do ser. E, em última instância, de acordo com Buzzi (1999, p. 15), "a linguagem é a casa do ser. No 
conhecimento se mostra o ser. O pensamento está no interesse do ser [...]”. Nessa compreensão do ontológico, que Heidegger leva às últimas consequências, o ser humano nada mais é que o lugar ou a memória do ser, o guarda do ser. "A partir daí, a compreensão do ser não supõe apenas uma atitude teorética, mas todo o comportamento humano. O homem inteiro é ontologia” (LÉVINAS, 1997, p. 22).

Ao anunciar o humano como "pastor do ser", a ontologia reafirma a cultura da imanência, da mesmidade. De modo que "à guisa de preocupação em ser, à guisa de ser-aí, à guisa de ser-no-mundo, à guisa de ser-com-os-outros, à guisa de ir-para-a-morte, importa no ‘acontecimento' de ser deste ser mesmo” (LÉVINAS, 1997, p. 253). Em outras palavras, a pergunta pelo sentido do ser culmina na preocupação pelo ter-de-ser. "A maneira como o ser é em relação ao seu próprio nada é o si mesmo. O 'ter-de' do ter-de-ser é compreendido a partir de seu ser" LÉVINAS, 2003b, p. 77). A existência humana no mundo é compreendida como busca incessante pelo pensar e tornar presente o ser. Servindo como cópula ou de síntese entre predicados, o verbo ser passou a exercer uma função nominal e substantiva. Por isso a tese de Lévinas que remonta ao significado do verbo ser para além de um sentido auxiliar. E a ontologia, enquanto manifestação do sentido de ser e expressão conceitual, caracteriza-se justamente na força de dizer que "algo é isso ou aquilo”.

A boa vontade, firmada na autonomia da razão, mantém-se nessa mesma lógica. Consequentemente, o caminho do êxodo, enquanto possibilidade de libertação, não teria muita chance de acontecer. De modo que, no dizer de Pivatto (2001, p. 85), "uma das intuições básicas [de Lévinas] consiste no peso e na solidão do homem imantado ao ser e por ele rodeado". O mais dramático é que "as tentativas de libertação e de êxodo ensaiados ao longo da história da tradição ocidental não o livraram do peso de sua solidão. Os caminhos que apontavam para a transcendência acabavam no eterno retorno ao ponto de partida”. Então, Lévinas procura indicar um movimento exodal, uma saída que liberta o sujeito do peso do ser. Tal movimento reporta à significação ética que se dá pela nudez de um rosto que se faz proximidade. 
É claro, o itinerário levinasiano se realiza aos poucos. O que aparece decisivo, desde o início, é sua a intuição de que é preciso sair das amarras do ser, sem cair na tentação de uma nova totalidade. Na análise de Costa (2000, p. 25) "sair do ser é criar um intervalo no ser, sem negá-lo. Criar tal intervalo no ser é pôr a descoberto que o ontológico-fundamental-existencial não é primeiro, pelo contrário, é segundo”. Daí a tensão ou provocação que abre a possibilidade de mudança é, justamente, a entrada do rosto de outrem que me visita. "O Outro provoca este movimento ético, na consciência, e desconcerta a boa consciência que coincide o mesmo consigo mesmo [...]” (LÉVINAS, 2001, p. 101). Revela-se, então, o vestígio de Deus que se faz proximidade no rosto que me torna vulnerável. Em última instância, estamos diante do cerne do pensamento levinasiano, segundo o qual, "nenhuma linha do que escrevi fica de pé sem isto. Eis o que é a vulnerabilidade. Somente um eu vulnerável pode amar o próximo" (LÉVINAS, 2002, p. 129).

\section{Um desassossego}

Sair de si é ocupar-se do outro, de seu sofrimento e de sua própria morte. $\mathrm{Eu}$ não digo que de maneira alguma que isso se faça com alegria de coração, que isso não é nada, nem sobretudo que isso seria uma cura contra o horror ou o cansaço de ser ou contra o esforço de ser, uma maneira de distrair-se de si. Eu penso que é a descoberta do fundo de nossa humanidade, a própria descoberta do bem no encontro de outrem eu não tenho medo do termo "bem"; a responsabilidade para com o outro é o bem. Isso não é agradável, é bem. (LÉVINAS, 2007, p. 82-83).

No dizer de Amós Oz (2004, p. 53), “precisamos de um senso de justiça, mas precisamos também de senso comum, de imaginação, uma capacidade profunda de imaginar o[a] outro[a], às vezes nos colocarmos na pele do[a] outro[a]”. Para tanto, implica também soprar nas brasas que, sob as cinzas do já dito, ainda guardam centelhas do dizer da esperança. Daí que, no dizer de Chalier (1993, p. 31), “o espírito, concentrado na letra, aguarda a solicitação de cada pessoa que tenha inteligência e o coração alerta, uma vez que é animado pelo desejo de 'fazer sair um pouco de água' de textos que se tornaram desérticos aos olhos de muitos”. 
Quando, ainda nos anos de 1930, Lévinas (2006, p. 36) reflete o clima do hitlerismo, dizendo que "a vontade de poder de Nietzsche que a Alemanha moderna reencontra e glorifica não é apenas um novo ideal, mas é um ideal que traz consigo sua forma própria de universalização: a guerra, a conquista”, o autor em tela testemunha um momento em que a humanidade vive a angústia da vontade de poder ser. Daí a sensibilidade levinasiana: "nessa fadiga de ser [...], nessa história Da evasão, eu tive talvez o sentimento de estar atormentado por alguma coisa única e que ainda me atormenta" (LÉVINAS, 2007, p. 80). Um desassossego que, de certa forma, assemelha-se à inquietude de Moisés que, diante da revelação na sarça ardente, percebe-se convocado ao projeto do êxodo, em favor do povo que clamava, por libertação, no Egito.

Na medida em que procura explicitar a dinâmica de escravidão que emerge do paradigma ontológico, Lévinas conduz a análise por perspectivas insólitas. Com efeito, o autor arrola a peculiar categoria do há ou Il y a, uma expressão que designa a forma impessoal francesa do verbo haver. É o próprio autor quem explica o sentido emergente:

Imaginemos o retorno ao nada de todos os seres: coisas e pessoas. É impossível colocar este retorno ao nada fora de todo acontecimento. Mas, e este próprio nada? Alguma coisa ocorre, fossem a noite e o silêncio do nada. A indeterminação desse "alguma coisa ocorre" não é a indeterminação do sujeito, não se refere a um substantivo. Ela designa como que o pronome da terceira pessoa na forma impessoal do verbo [no francês, os verbos impessoais são acompanhados de um pronome de terceira pessoa] - de modo algum um autor mal conhecido da ação, mas o caráter da própria ação que, de alguma maneira, não tem autor, é anônima [...]. O há, em sua recusa de tomar uma forma pessoal, é o "ser em geral". (LÉVINAS, 1998a, p. 67).

Nesse exercício intelectivo, de imaginar o retorno de todas as coisas e pessoas ao estado do nada (ex nihilo), vislumbra-se a maneira da manifestação do ser despegado de todas as formas (entes), no estado do puro ser, o ser em si. Mas, mesmo na ausência de todas as coisas, ainda haveria alguma coisa, espécie de um murmurinho. Essa é justamente a experiência do há ser, no sentido levinasiano. "Quaisquer que sejam meus empreendimentos, quaisquer que sejam meus 
movimentos, qualquer que seja meu repouso, o há (il y a) ser. [Mas], há (il y a) é anônimo" (LÉVINAS, 2007, p. 81).

Em diversos escritos, Lévinas retoma essa ideia do há, sempre com imagens metafóricas que procuram traduzir a ideia em que o ser humano se vê atemorizado diante da aventura do ser. Assim como no "está chovendo" ou no "está fazendo calor”, o há descreve o ser em seu anonimato e indigência: "[...] Não há somente qualquer coisa que é, mas há (il y a) acima ou através de algumas dessas coisas, há um processo anônimo do ser. Sem portador, sem sujeito, como na insônia, este não para de ser - há (il y a)” (LÉVINAS, 2007, p. 81). Em última instância, o há remonta à face neutra do ser. O há não é ser, mas também não é nada. Mesmo que todas as coisas e pessoas fossem reduzidas ao nada, ainda assim permaneceria um sussurro de alguma coisa. "De fato, insisto na impessoalidade do 'há'; 'há', como 'chove' ou ‘é de noite'. E não há nem alegria nem abundância; é um ruído que volta depois de toda a negação do ruído. Nem nada, nem ser” (LÉVINAS, 2000, p. 40).

A acepção francesa do Il y a - há - não se aproxima do es gibt heideggeriano. O es gibt é a expressão alemã que literalmente significa há. Mas, diferente do há levinasiano que evoca uma experiência de horror, o há em Heidegger se oferece como uma dádiva: o que existe dá-se, manifesta-se. Em Lévinas, o há não é interpretado como uma categoria que designa a alegria do que existe, sua abundância, mas como o fenômeno do ser impessoal e anônimo, é uma experiência desagradável.

Da mesma maneira em que uma criança, acometida de insônia, vive a experiência de pavor diante do silêncio e da solidão da noite que parece perdurar infindavelmente, o há remete ao fenômeno do ser impessoal. Em outras palavras, na expressão do há, indica-se uma espécie de perseguição da qual é preciso sair. Ao invés da facticidade de um existente humano obcecado em ser, Lévinas introduz a ideia na qual o há alude uma experiência em ser que é tomada pelo horror que lembra, em certa medida, a náusea sartriana. Diante do há, emerge uma espécie de 
vertigem que acomete o pensamento que se curva "sobre o vazio do verbo existir, de que não se pode, ao que parece, nada dizer e que somente se torna inteligível em seu particípio - o existente -, no que existe” (LÉVINAS, 1998a, p. 15).

No caminho interpretativo de Chalier (1993, p. 49), pode-se indicar que a categoria do há remete ao primeiro momento que se pode imaginar antes da criação, conforme descreve o livro do Gênesis, em que "a terra estava vazia e vaga, as trevas cobriam o abismo" (Gn 1.2). A experiência do há é o instante anterior à manifestação da palavra que cria a luz: "Deus disse: 'haja luz' e houve luz. Deus viu que a luz era boa, e Deus separou a luz e as trevas" (Gn 1.3). Neste momento segundo, vislumbra-se o nascimento da criatura confrontada com a palavra criadora de Deus, a absoluta Alteridade.

O Verbo criador é, no ato da criação, uma garantia de soberania exatamente porque ele é palavra. A palavra desprende-se daquele que a pronuncia; ela voa. Deus verdadeiramente Deus não moldou ele mesmo a criatura, não pôs, como o demiurgo, a mão na massa. (LÉVINAS, 1998a, p. 32).

Anterior à percepção de que a criação era boa, Deus distingue e nomeia o que é criado. A não indiferença do criador indica que o sujeito humano não é um ser-aí, alguém abandonado no mundo ou um ser anônimo. $\mathrm{O}$ eu que é chamado à vida, isto é, a sair do anonimato do há, dá-se conta de sua singularidade, que é alguém separado em relação aos outros. O existente que toma consciência de seu existir, inaugura o movimento que Lévinas (2000, p. 43) denomina de hipóstase, “a passagem que vai do ser a um algo, do estado de verbo ao estado de coisa”. Ou ainda, “o acontecimento da hipóstase é o presente. O presente que parte de si mesmo ou, melhor dito, é a saída de si mesmo. Implica um desenraizamento na trama infinita - sem começo nem fim - do existir. [...] Presente, 'eu': a hipóstase é liberdade” (LÉVINAS, 1993a, p. 89). Então, na criação, um mundo é oferecido à criatura humana.

Cabe destacar que a experiência original, conforme relatam os primeiros versículos do Gênesis, remete à singularidade e à justificação da criatura humana, 
em que a ideia de Deus é transcendida a um antes pré-original, inclusive anterior ao existir. Pivatto (2003, p. 192) interpreta que "o distanciamento de Deus é levado tão longe, a ab-solução é tão completa que Deus é transcendente até à ausência, até à confusão possível com a indeterminação do puro existir ou há.” Se tudo permanecesse no há, prossegue Pivatto, "reinaria a impessoalidade, o anonimato, a materialidade sem rosto, sem nome e sem forma. [...] O há é fonte de mitos, de ídolos, de tabus, de formas religiosas que o ser pode suscitar”.

Sob a afirmação do primado ontológico, o momento da palavra criadora é ignorado. Aliás, não há criação. O há - es gibt - heideggeriano apresenta-se já sendo, sem "pedir passagem", arrogando-se no direito de pôr-se afirmativamente. A percepção de que "há ser" é o álibi que autoriza a luta pela própria existência. Sou, logo existo! Por isso, as circunstâncias e os “entes" que se apresentam como empecilhos precisam ser administrados e conformados à dinâmica do Dasein. Trata-se de uma existência jogada à própria sorte, em que cada ser, lutando pelo seu lugar ao sol, entende-se no "[...] direito de afastar do seu caminho aquilo que ameaça diminui-lo, entristecê-lo, ou proibir-lhe o aumento da sua potência” (CHALIER, 1993, p. 56).

Ora, não obstante a toda preocupação em existir, há sempre a possibilidade trágica e angustiante da morte. O homem é um ser para a morte. Por isso, Lévinas intenta mostrar que a perspectiva da ontologia encerra um significado que nega o antropológico. É isso que acarreta o peso insuportável da ontologia. Para Lévinas, observa Chalier (1993, p. 50), “[...] não é a morte que faz o trágico da existência, mas a impossibilidade de escapar à fatalidade do ser, à sua influência sufocante e absurda quando não é justificada por uma Palavra que a oriente”.

A perseverança ou dureza do ser não constitui o fundamento último do humano. Ao evocar a categoria do há, Lévinas (2007, p. 82) não a concebe como afirmação positiva do ser, mas como instância anterior à Palavra criadora que insufla um intermitente horror em ser. "Não é a angústia do nada, é o horror do há 
(Il y a) da existência. Não é o medo da morte, é o 'demais' de si mesmo”. O horror do há é um constante sussurro que me faz recordar que para além do ser há um 'choque' que questiona minha soberania e coloca-me diante do rosto do outro. "O choque do divino, a ruptura da ordem imanente, da ordem que eu posso abarcar, da ordem que eu posso ter por meu pensamento, da ordem que pode tornar-se minha, eis o rosto de outrem" (LÉVINAS, 2007, p. 82). E diante desse rosto, abrese a razão do humano: o bem que se faz encontro com outrem.

Para indicar que o peso do ser não constitui a realidade mais fundamental do humano, Lévinas, como fenomenólogo, busca na experiência cotidiana expressões que indicam a resistência do sujeito face ao primado ontológico. Com efeito, em Da existência ao existente, o autor apresenta, distante de um sentido moral ou meramente psicológico, a preguiça e o cansaço como manifestações que indicam a resistência do humano ante a necessidade de ser. "O caráter penoso do ato de que o preguiçoso se abstém não é um conteúdo psicológico qualquer de dor, mas uma recusa de empreender, de possuir, de ocupar-se" (LÉVINAS, 1998a, p. 29). E o cansaço, por sua vez, é cansar-se de ser. A preguiça e a lassidão são experiências existenciais que revelam que o sentido da vida humana não está no conatus essendi, necessidade de ser que suplanta a vida do/a Outro/a.

O há, o cansaço, a preguiça são algumas das categorias que Lévinas busca do cotidiano para formular metaforicamente sua intuição de que o sentido da vida não consiste, prioritariamente, em "cuidar do ser", como entende Heidegger em sua ontologia fundamental, um cuidado que, no fundo, guarda a lógica da obsessiva aventura humana que conduz a civilização aos horrores como, por exemplo, de Auschwitz. E à medida que mergulha na tarefa de indicar o sentido da saída do ser, semelhante ao êxodo bíblico, Lévinas perfila seu pensamento em direção à dignidade humana implicada no cuidado com o/a Outro/a. No fundo dessa "descoberta", há o elã que insufla a sabedoria do amor a partir do rosto que dá sentido ao humano - sentido que humaniza, liberta. Em palavras levinasianas, “[...] o rosto, por trás da feição que ele se dá, é como exposição de um ser à sua 
morte, o sem defesa, a nudez e a miséria de outrem. Ele é também o mandamento de tomar a si, a seu cargo, outrem, de não o deixar só; você ouve a palavra de Deus” (LÉVINAS, 2007, p. 85).

\section{Vestígio de Deus no rosto do/a outro/a}

Lévinas (1998a, p. 113) anuncia que a condição humana tem seu significado mais profundo em assumir sua existência como abertura ao/à Outro/a. Porém, “outrem, como outrem, não é somente um alter ego. Ele é o que eu não sou: ele é o fraco enquanto sou o forte; ele ó pobre; ele é ‘a viúva e o órfão'.” Percebe-se que, sem se enquadrar no pensamento existencialista, mas partindo da "existência", Lévinas indica o drama que perpassa o sentido do humano. Com efeito, o problema que salta aos olhos não é mais a questão ontológica, isto é, do ser humano essencialmente preocupado com o ser dos entes, mas da relação do sujeito (eu) com a questão da alteridade, relação esta que se revela na relação ética.

Diferente de Heidegger, que contemplava o "ser-com" na dinâmica da inautenticidade do "ser-aí", Lévinas entende que, diante de Outrem, emerge um sentido que toca a sensibilidade do sujeito a partir da própria epifania do rosto que se faz próximo. Desse modo, por exemplo, diante do fenômeno da morte, o filósofo da alteridade expressa que anterior à minha morte, está a morte do/a Outro/a que me interpela e solicita a minha presença. "A morte do outro homem me põe em causa e questiona como se desta morte, invisível ao outro que aí se expõe, eu me tornasse o cúmplice, por minha indiferença” (LÉVINAS, 2002, p. 215).

Entende-se, nesse sentido, que Lévinas reflete a morte não como uma existência autêntica descrita por Heidegger. Neste, há a ideia de que a morte ainda pode ser assumida pelo sujeito - "possibilidade da impossibilidade”. Enquanto que, no caso levinasiano, a morte chega, toma-me de surpresa, sem que possa tomar a iniciativa. A morte é a "impossibilidade da possibilidade”. O esforço desprendido por Heidegger em estabelecer o primado do ser, enquanto movimento 
do Dasein, não elimina de todo a presença de certa alteridade. A analítica existencial indica que enquanto ser-aí, jogado sem escolha perante suas possibilidades, o Dasein se depara diante do "ser-com”. Seja diante da tradição que me precede e me envolve, seja diante do ente que não sou eu, sou implicado pelo “ser-com”.

Especificamente, na temática do ser-para-a-morte, Heidegger tem presente a morte do/a Outro/a. Porém, não é tanto uma atenção por Aquele/a que morre, senão que este/a me faz tomar consciência que também vou morrer. Outrem entra no discurso ontológico à medida que interfere no Dasein, expondo-o à condição de finitude. De modo que, no dizer de Lévinas, “a relação ética, em Heidegger, o Miteinandersein [sic], ser-com-outrem, não passa de um momento de nossa presença ao mundo" (LÉVINAS, 1997, p. 158). Em outras palavras, a relação ética é uma situação secundária, em que o ser com o/a Outro/a não expressa relação face a face. O Dasein heideggeriano é alguém sem rosto, é um sujeito impessoal (anônimo). É o eu que vive a aventura do ser, como o Ulisses da epopéia grega, o qual viaja pelo mundo e, ao final, retorna a Ítaca, sua ilha.

Em contrapartida, a excedência ou a saída do sujeito, em Lévinas, assume a condição de Abraão. Não é simplesmente um eu que sai de si mesmo, num sair por sair ou num movimento de eterno retorno para si mesmo. Despertado do anonimato, o eu é chamado pelo nome (pessoalidade) a sair de si mesmo para ir ao encontro da interpelação do outro. Em outras palavras, no dizer de Melo (2003, p. 78), “[...] é o movimento daquele que, ouvindo a voz do Outro, se põe a caminho, sabendo que a estrada é incerta e que o destino apontado não é para ser possuído ou dominado".

A via aberta pelo pensador lituano-francês apresenta a possibilidade de pensar concretamente o sujeito humano comprometido com o outro humano. Trata-se, no dizer de Chalier (1993, p. 46), de um "projeto que anuncia o sentido de todas as investigações ulteriores de um filósofo que, precisamente, não faz 
concessões à sabedoria das nações". Ou dito de outra maneira, a ética da alteridade emerge como uma encruzilhada humana diante da qual a lógica do conatus essendi é firmemente questionada. No lugar de uma concepção antropológica hobbesiana que propaga que o homem é o lobo do homem, irrompe o sentido do humano no rosto de outrem que solicita hospedagem a mim.

Essa não indiferença tece o movimento do eu para o outro. É a responsabilidade para com o próximo. Trata-se, por conseguinte, da “[...] ruptura do Mesmo, sem que o Mesmo se retome nos seus costumes; sem envelhecimento novidade - transcendência. Ela se diz, toda inteira, em termos éticos" (LÉVINAS, 2002, p. 32). Ou ainda, para além da percepção do eu penso, é a sensibilidade ética que se exprime em um "[...] arrancar-se de si mesmo para o outro, no ato de dar ao outro o pão de sua boca. [...] A identidade do sujeito se acusa aqui não mediante um repouso em si, mas mediante uma inquietude que me persegue fora da nudez de minha substancialidade” (LEVINAS, 2003a, p. 218). Em suma, sentido do eisme aqui, na proximidade ou relação face a face, que articula ética, justiça e bondade. Ou, se se preferir, religião sem ontologia. "Este vínculo com outrem que não se reduz à representação de outrem, mas à sua invocação, e onde a invocação não é de compreensão, chamo-a religião" (LÉVINAS, 1997, p. 28). Relação sem ontologia ou interesse, em que a relação, encontro face a face na ética, tem precedência.

Des-inter-essamento da responsabilidade por outrem e por seu pasado passado, para mim, imemorial - a partir do futuro da profecia - sem os quais o Deus desconhecido ficaria inaudível em sua glória, rompendo sua negativa teologia sem palavra - eis a temporalidade na qual se desata na ética a intriga do ser e da ontologia. (LÉVINAS, 1997, p 204).

Des-inter-essamento, movimento de saída do ser, que sustenta a possibilidade de uma teologia desgarrada da pretensão ontológica. Teologia que testemunha e fala da fé de Abraão, descrita por Kierkegaard (2008, p. 62), como fé no absurdo, um salto no escuro, na medida em que "isso não faz parte do cálculo humano". Paradoxo da fé que, ante o silêncio de Deus e, portanto, ausência de compreensão ou justificativa, inclusive racional, sinaliza para uma questão ética 
fundamental, a partir da qual não há “qualquer dever para com Deus”. Ou seja, “o dever de amar o próximo, é dever, na proporção em que este amor está afeto a Deus; entretanto no dever, não entro em relação com ele, porém com o próximo ao qual amo”. De modo que dizer que ama a Deus, uma ideia de Deus, é como que amar um fantasma, uma projeção de si mesmo.

De outro modo, há a responsabilidade pelo Outro/a amar o próximo - eisme aqui! "Não é metáfora: em outrem, há presença real de Deus. Na minha relação a outrem, escuto a Palavra de Deus. [...] Não digo que outrem é Deus, mas que, em seu rosto, entendo a Palavra de Deus" (LÉVINAS, 1997, p. 151). Imprime-se, aqui, o sentido de uma Palavra ética que possibilita pensar uma teologia sem amarras ontológicas. Com efeito, para Lévinas (2000, p. 89), “dizer: eis-me aqui. Fazer alguma coisa por outrem. Dar. Ser espírito humano é isso. A encarnação da subjetividade humana garante a sua espiritualidade [...]”.

Quando parece pairar o silêncio de Deus, tal como junto à cruz do Nazareno, sem triunfo, há um rosto que clama e solicita o humano, desejo de hospitalidade, solidariedade, que não é a presença de um poder que se impõe a qualquer custo, mas “eis-me aqui” e, logo, “envia-me”. Amor a serviço do amor que Lévinas designa pelo termo vestígio. "Mas o vestígio não é uma palavra a mais: é a proximidade de Deus no rosto do meu próximo” (LÉVINAS, 1997, p. 89). Vestígio da utopia, na entrada de um/a Outro/a, que anuncia o tempo da esperança quando aparentemente já não há esperança.

O tempo é pura esperança. É mesmo o lugar natal da esperança. Esperança de um mundo realizado, onde o homem e o seu trabalho não são mais mercadorias. Esperança e utopia sem as quais a atividade que realiza o ser - quer dizer a humanidade - não pode começar nem continuar na sua longa paciência de ciência e esforço. (LÉVINAS, 2003b, p. 113).

Então, pela trilha aberta por Lévinas, há o anúncio de uma boa-nova que comunica que o Verbo se fez carne. Tal como escreve Arendt (2009, p. 259), “esta fé e esta esperança no mundo talvez nunca tenham sido expressas de modo tão 
sucinto e glorioso como nas breves palavras com as quais os Evangelhos anunciaram a 'boa-nova': 'Nasceu uma criança entre nós'." Eis o tempo do/a Outro/a que sinaliza também a possibilidade de uma teologia que se esvazia da ontologia, do peso do ser, para deixar o Inaudito entrar. Se se quiser, uma teologia vazia de si mesma, até mesmo sem necessidade de Deus (GARAUDY, 1995), porque a sabedoria do amor, como desejo do/a Outro/a, sinaliza a Palavra que se esvazia a si mesma, para deixar entrar, no sopro da vida, o humano. Em suma, amorosidade que ecoa o Deus da Vida como desejo do/ Outro/a em mim. Vestígio do Inaudito, sopro de Deus que clama no rosto de Outrem: “ama ao próximo como a ti mesmo" (Mc 12.30).

\section{Conclusão}

O Deus revelado da nossa espiritualidade judaico-cristã [...] mostra-se apenas pelo seu vestígio [...]. Ir na Sua direção não é seguir esse vestígio que não é um sinal, é ir na direção dos Outros que se mantêm nessa pista. (LÉVINAS, 1998b, p. 245).

A reflexão proposta por este artigo que se cetrou na possibilidade de pensar uma teologia sem ontologia, a partir de uma evasão ética, não encontra aqui seu epílogo. A refexão deve continuar. Não obstante, cabe destacar a possibilidade aberta pela ética levinasina, em que se apresenta o sentido de um êxodo também do teológico, o resgate de uma teologia a partir da manifesta do rosto do/a Outro/a. Tal como no êxodo bíblico que irrompe a partir da experiência mosaica, na Epifania da sarça ardente (Ex 3.2), a ética da alteridade irrompe como sentido de um itinerário de saída, o humano que se abre, de forma hospitaleira, à humanidade, à vida de Outrem.

Antes que eu me dê conta, o/a Outro/a já está diante de mim, como na sarça que arde e testemunha o vestígio de uma presença no rosto do próximo. A manifestação de um rosto me toca e solicita acolhida, hospitalidade. O eu para o outro como travessia, um movimento ético que aflora e desafia também o quefazer teológico. Daí o sentido de uma teologia implicada na ética, como possibilidade 
de uma teologia desinteressada, sem ontologia, sem dogmas, porque se trata de uma razão da fé habitada pelo Logos que se faz carne.

E a manifestação de um rosto sinaliza, por si mesmo, uma visitação, transcendência - desejo de Deus no rosto do "estranjeiro e possivelmente nu, indigente e indesejável". Eis o sentido do humano que se revela "no rosto que me suplica, irrecusavelmente rosto voltado para mim pondo-me em questão”. Em suma, palavra de Deus que vem à ideia, sem que isso implique uma "nova prova da existencia de Deus" (LÉVINAS, 2002, p. 221). Eis o sentido do divino no humano, ideia de Deus que clama no rosto do próximo como sabedoria do amor a serviço da vida. Nessa perspectiva, os passos do itinerário levinasiano permite pensar o sentido de uma evasão da teologia, sem as amarras da ontologia, do essencialismo dogmático.

\section{REFERÊNCIAS}

A BÍBLIA DE JERUSALÉM. São Paulo: Paulus, 1989.

ARENDT, Hannah. Entre o passado e o futuro. São Paulo: Perspectiva, 2009.

BUCKS, René. A Bíblia e a ética: a relação entre a filosofia e a sagrada escritura na obra de Emmanuel Lévinas. São Paulo: Loyola, 1997.

BUZZI, Arcângelo R. Introdução ao pensar: o ser, o conhecimento, a linguagem. 26. ed. Petrópolis: Vozes, 1999.

CHALIER, Catherine. Lévinas: a utopia do humano. Lisboa: Instituto Piaget, 1993.

COSTA, Márcio Luiz. Lévinas: uma introdução. Petrópolis: Vozes, 2000.

DALLA ROSA, Luís Carlos. Educar para a sabedoria do amor: a alteridade como paradigma educativo. São Paulo: Paulinas, 2012.

FABRI, Marcelo. Desencantando a ontologia: subjetividade e sentido ético em Levinas. Porto Alegre: EdiPUCRS, 1996.

GARAUDY, Roger. Deus é necessário? Rio de Janeiro: Zahar, 1995.

Horizonte, Belo Horizonte, v. 16, n. 51, p. 1218-1239, set./dez. 2018 - ISSN 2175-5841 
KIERKEGAARD, Sören. Temor e tremor. São Paulo: Hemus, 2008.

LEGRAND, Gerard. Os pré-socráticos. Rio de Janeiro: Jorge Zahar, 1997.

LÉVINAS, Emmanuel. Da existência ao existente. Campinas: Papirus, 1998a.

LÉVINAS, Emmanuel. De Deus que vem à ideia. Petrópolis: Vozes, 2002.

LÉVINAS, Emmanuel. De otro modo que ser: o más allá de la esencia. Salamanca:

Sígueme, 2003a.

LÉVINAS, Emmanuel. Descobrindo a existência com Husserl e Heidegger. Lisboa: Instituto Piaget, 1998b.

LÉVINAS, Emmanuel. Deus, a morte e o tempo. Coimbra: Almedina, 2003b.

LÉVINAS, Emmanuel. El tiempo y el otro. Barcelona: Paidós, 1993a.

LÉVINAS, Emmanuel. Entre nós: ensaio sobre a alteridade. Petrópolis: Vozes, 1997.

LÉVINAS, Emmanuel. Entrevistas. In: POIRIÉ, François. Emmanuel Lévinas: ensaios e entrevistas. São Paulo: 2007, p. 51-134.

LÉVINAS, Emmanuel. Ética e infinito. Lisboa: Edições 70, 2000.

LÉVINAS, Emmanuel. Humanismo do outro homem. 2. ed. rev. Petrópolis: Vozes, 1993b.

LÉVINAS, Emmanuel. La realidad y su sombra: libertad y mandato, trascendencia y altura. Madrid: Trotta, 2001.

LÉVINAS, Emmanuel. Los imprevistos de la historia. Salamanca: Sígueme, 2006.

MATE, Reyes. Memórias de Auschwitz: atualidade e política. São Leopoldo: Nova Harmonia, 2005.

MELO, Nélio Vieira de. A ética da alteridade em Emmanuel Levinas. Porto Alegre: EdiPUCS, 2003.

MíGUEZ, Néstor; MO SUNG, Jung; RIEGER, Joerg. Para além do espírito do império. São Paulo: Paulinas, 2012.

OZ, Amós. Contra o fanatismo. Rio de Janeiro: Ediouro, 2004.

PIVATTO, Pergentino. A questão da subjetividade nas filosofias do diálogo - o exemplo de Levinas. Veritas, Porto Alegre, v. 48, n. 2, p. 187-195, jun. 2003. 
PIVATTO, Pergentino S. Ética da alteridade. In: OLIVEIRA, Manfredo A. de. Correntes fundamentais da ética contemporânea. 2. ed. Petropólis: Vozes, 2001. p. 79-97.

RIBEIRO JÚNIOR, Nilo Ribeiro. Sabedoria da paz: ética e teo-lógica em Emmanuel Levinas. São Paulo: Loyola, 2008. 